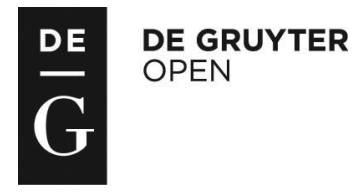

\title{
EFFECTS OF HOT AND SWEET RED PEPPERS (CAPSICUM ANNUUM) AS FEED SUPPLEMENTS ON PIGMENTATION, SENSORY PROPERTIES AND WEIGHT GAIN OF RAINBOW TROUT (ONCHORHYNCHUS MYKISS)*
}

\author{
Mahmut Yanar' ${ }^{1}$, Hakan Murat Büyükçapar², Yasemen Yanar ${ }^{1 \star}$ \\ ${ }^{1}$ Faculty of Fisheries, University of Çukurova, 01330, Adana, Turkey \\ ${ }^{2}$ Department of Fisheries, Faculty of Agriculture, University of Kahramanmaraş Sütçü İmam, 46100 \\ Kahramanmaraş, Turkey \\ •Corresponding author: yyanar@cu.edu.tr
}

\begin{abstract}
This study was conducted to evaluate the effects of diets, including $0.5,2$ and $4.4 \%$ dried hot or sweet red pepper and a control diet without added red pepper, on pigmentation, sensory properties and weight gain of rainbow trout, with average initial weight of $60 \mathrm{~g}$, for a rearing period of 80 days. Both red pepper types had similar effects on the carotenoid accumulation, weight gain and sensorial properties of the fish $(\mathrm{P}>0.05)$. Total carotenoid accumulation in the fish muscle increased significantly with increasing inclusion of red peppers. However, only the diet consisting of $4.4 \%$ hot or sweet red pepper provided adequate carotenoid accumulation in the fillet of the fish, that is, the desired colouration in the fish. Fish fed diets containing red peppers exhibited higher appearance and colour scores compared to control group $(\mathrm{P}<\mathbf{0 . 0 5})$. Irrespective of being hot or sweet, red pepper can be successfully used as an alternative natural carotenoid source in rainbow trout diets.
\end{abstract}

Key words: red pepper, capsaicin, pigmentation, rainbow trout, sensory quality

Colour of fish flesh is one of the important quality parameters (Sigurgisladottir et al., 1997) because of consumer preference for red or pink-coloured products of salmonid fishes (Ostrander et al., 1976; Hatano et al., 1987; Gormley, 1992; Rounds et al., 1992; Sigurgisladottir et al., 1994; Skonberg et al., 1998). Therefore, adding carotenoid pigments into diet is regarded as one of the common management practices for marketing of farmed salmon (Moe, 1990). Carotenoids, especially astaxanthin, are responsible for providing the typical colour of salmonid muscle (Ando et al., 1992; Storebakken and No, 1992). In addition to pigmentation, carotenoids have also

\footnotetext{
*This study was supported by the Çukurova University Research Fund (No. FBE.2002.D.218).
} 
some other significant benefits to human being since there are increasing evidences that they decrease the risk of some cancers, cardiovascular diseases, and some other diseases (Ziegler, 1989; Gaziano and Hennekens, 1993; Mayne, 1996) and act as antioxidants (Palozza and Krinsky, 1992; Krinsky, 1993) and precursor of vitamin A (Devery and Milborrow, 1994; Nagao et al., 1996). Because fish, like other animals, are not able to synthesize carotenoids de novo (Goodwin, 1984), they have to obtain them from dietary sources. Fillet pigmentation of salmonids has been accomplished by suplementing their diets with synthetic carotenoids such as astaxanthin and canthaxanthin. However, recent efforts have focused on natural compounds as alternative to synthetic carotenoids because of concerns about the use of synthetic additives and their high cost.

Red pepper (Capsicum annuum) is a good natural carotenoid source, and also inexpensive and abundant in Turkey. Red pepper contains 1500-2500 mg total carotenoids $\mathrm{kg}^{-1}$ (Erkek and Taluğ, 1990; Ergün and Erdem, 2000; Topuz and Özdemir, 2007) with the majority being keto-carotenoids, such as capsanthin and capsorubin, each of which has an important role in red pigmentation of trout (Torrissen et al., 1989). It has been shown that red pepper could be used for pigmentation of salmonids (Vernon-Carter et al., 1994; Yanar et al., 1997; Talebi et al., 2013) and Pacific white shrimps (Arredondo-Figueroa et al., 2003). In addition to pigmentation, it has been reported that carotenoids from red pepper increased growth in rainbow trout (Talebi et al., 2013) and improved reproductive performance in yellow tail (Agius et al., 2001; Agius et al., 2002). However, there is currently no information available on what type of red pepper (hot or sweet) is more suitable for pigmentation, growth or sensorial properties in aquatic animals. It is suggested that capsaicin, responsible for the hot taste in the red pepper, increased yolk pigmentation in laying hens (Gurocak, 1983; Gonzalez et al., 1999; Vicente et al., 2007) and improved weight gain and feed conversion ratio in broilers (Galib et al., 2011). Therefore, similar effects might be also observed in fish.

The present study was designed to determine the effects of diets including various levels of hot or sweet red pepper on pigmentation, sensory properties and weight gain in rainbow trout.

\section{Material and methods}

\section{Experimental procedure}

This experiment was carried out in floating net cages $(1 \times 1 \times 1 \mathrm{~m})$ between February and June, in the Sir Dam Lake, Turkey. The fish were obtained from a local commercial breeder and acclimated to the experimental conditions in some net cages for two weeks before the experiment. During this period, the fish were fed the control diet (or basal diet). Thirty-five rainbow trout, Onchorhynchus mykiss with average initial weight of 58-60 g were stocked per cage with two replicates for each experimental diet.

The fish were fed ad libitum by hand three times a day during the experimental period of 80 days. Body weight and total carotenoid content of fillet were measured 
every 20 days. All the fish were used for growth, but four individuals from each cage were evaluated for carotenoid analysis. During the measurements, the fish were anaesthetized using 2-phenoxyethol at a dose of $0.15 \mathrm{ml} \mathrm{L}^{-1}$.

Water temperature, $\mathrm{pH}$ and dissolved oxygen level were measured daily. Throughout the experiment period, the temperature was between 7 and $12^{\circ} \mathrm{C}$, dissolved oxygen level was above $8.5 \mathrm{mg} \mathrm{L}^{-1}$ and $\mathrm{pH}$ was around 7.3.

Experiments were conducted according to the European Council Directive 6/609/ EEC regarding the protection of animals used for experimental and other scientific purposes.

\section{Feeding trial}

Seven isonitrogenous and isoenergetic experimental diets were prepared by adding various levels of dried hot and sweet red pepper to the basal diet. Experimental diets were designed as follows:

- Diet without any pigment sources (control diet)

- Diet supplemented with $0.5 \%$ hot red pepper (containing $7.5 \mathrm{mg}$ total carotenoid and $3.02 \mathrm{mg}$ capsaicin $\mathrm{kg}^{-1}$ )

- Diet supplemented with $2 \%$ hot red pepper (containing $30 \mathrm{mg}$ total carotenoid and $12.10 \mathrm{mg}$ capsaicin $\mathrm{kg}^{-1}$ )

- Diet supplemented with 4.4\% hot red pepper (containing $65 \mathrm{mg}$ total carotenoid and $26.62 \mathrm{mg}$ capsaicin $\mathrm{kg}^{-1}$ )

- Diet supplemented with $0.5 \%$ sweet red pepper (containing $7.5 \mathrm{mg}$ total carotenoid and $0.21 \mathrm{mg}$ capsaicin $\mathrm{kg}^{-1}$ )

- Diet supplemented with $2 \%$ sweet red pepper (containing $30 \mathrm{mg}$ total carotenoid and $0.84 \mathrm{mg}$ capsaicin $\mathrm{kg}^{-1}$ )

- Diet supplemented with $4.4 \%$ sweet red pepper (containing $65 \mathrm{mg}$ total carotenoid and $1.85 \mathrm{mg}$ capsaicin $\mathrm{kg}^{-1}$ )

Table 1. Main feed ingredients and proximate composition of basal diet

\begin{tabular}{lcllc}
\hline \multicolumn{1}{c}{ Feed ingredients } & Percentage (\%) & Chemical composition & Percentage (\%) \\
\hline Fish meal & 47.5 & Crude protein & 44.5 \\
Soybean meal & 21 & Crude fat & 20.1 \\
Corn flour & 15 & Crude cellulose & 2.89 \\
Fish oil & 4 & Crude ash & 13 \\
Sunflower oil & 10 & Dry matter & 88 \\
Di calcium phosphate & 0.5 & Energy content $(\mathrm{ME} \mathrm{kg/cal)}$ & 4100 \\
Methionine & 0.5 & & \\
Lysine & 0.5 & & \\
$*$ Vitamins and minerals & 1 & & \\
\hline
\end{tabular}

* Supplied per kilogram of feed: 25.000 i.u. vitamin A; 2000 i.u. vitamin $\mathrm{D}_{3} ; 100$ i.u. vitamin E; $150 \mathrm{mg}$ vitamin $\mathrm{C}$; $15 \mathrm{mg}$ vitamin $\mathrm{K} ; 20 \mathrm{mg}$ thiamine; $30 \mathrm{mg}$ vitamin $\mathrm{B}_{2} ; 10 \mathrm{mg}$ pantothenic acid; $20 \mathrm{mg}$ pyridoxin; $210 \mathrm{mg}$ inositol; $2000 \mathrm{mg}$ choline; $0.05 \mathrm{mg}$ vitamin $\mathrm{B}_{12} ; 220 \mathrm{mg}$ niacin; $0.5 \mathrm{mg}$ biotin; $5 \mathrm{mg}$ folic acid; $70 \mathrm{mg} \mathrm{Zn}$; $60 \mathrm{mg} \mathrm{Mg} ; 4 \mathrm{mg}$ Fe; $20 \mathrm{mg} \mathrm{Cu}$; $0.5 \mathrm{mg} \mathrm{Co}$; $0.05 \mathrm{mg} \mathrm{Se}$. 
Table 2. Proximate composition, carotenoid and capsaicin contents of dried red peppers

\begin{tabular}{l|c|c|c|c|c}
\hline $\begin{array}{c}\text { Carotenoid } \\
\text { sources }\end{array}$ & $\begin{array}{c}\text { Crude protein } \\
\%\end{array}$ & $\begin{array}{c}\text { Crude } \\
\text { fat } \%\end{array}$ & $\begin{array}{c}\text { Crude cellulose } \\
\%\end{array}$ & $\begin{array}{c}\text { Carotenoid content } \\
(\mathrm{mg} / \mathrm{kg})\end{array}$ & $\begin{array}{c}\text { Capsaicin content } \\
(\mathrm{mg} / \mathrm{kg})\end{array}$ \\
\hline Sweet red pepper & 12.3 & 16.1 & 21.1 & 1495 & 42 \\
Hot red pepper & 12.1 & 16.4 & 24.1 & 1503 & 605 \\
\hline
\end{tabular}

Dietary feed ingredients were ground into a meal with a laboratory grinder, and then blended into a homogenous doughy consistency by adding water and pelleted by pressing through a $3 \mathrm{~mm}$ die in a grinding machine. The pellets were then stored in plastic containers in a freezer at $-20^{\circ} \mathrm{C}$ until required. They were thawed before being fed to the fish. The feed ingredients used were provided by Pinar A.Ş., Izmir, Turkey, and hot and sweet red peppers by local producers. Leaves of both red peppers were dried in the shade, ground into meal, and then added to the basal diet at different levels.

Red peppers were harvested in Kahramanmaraş, Turkey in September. The contents of basal diet and red peppers are shown in Table 1 and Table 2, respectively.

\section{Proximate composition analysis}

Lipid was analysed by the method of Bligh and Dyer (1959). Ash and moisture contents were determined following AOAC (1984). Crude protein content was calculated by converting the nitrogen content determined by Kjeldahl's method $(6.25 \times \mathrm{N})(\mathrm{AOAC}, 1984)$, while crude cellulose was determined as described by AOAC (1990).

\section{Capsaicin analysis}

Capsaicin from red pepper was determined by method of Woodbury (1980). Sweet and hot red pepper samples were obtained by Soxhlet extraction of $10 \mathrm{~g}$ of ground peppers with $250 \mathrm{ml}$ of HPLC grade acetone (Merck) for 5 hours. The samples were vacuum evaporated to $5 \mathrm{ml}$ at room temperature. Bisphenol A (Aldrich), a common antioxidant, was used as an internal standard. $1 \mathrm{~g}$ of oleoresin and 30 mg Bisphenol A were dissolved in $5 \mathrm{ml}$ acetonitrile (Merck). A $2 \mathrm{ml}$ aliquot was filtered through a Sep-Pak C-18 cartridge (Alltech). Ten micro litres of these samples were then injected directly to the HPLC system (Waters Associates Model ALC/ GPC equipped with M.6000A pump, a U6K injection). $\mu$-Bondapak C-18 column $(300 \times 4 \mathrm{~mm}, 5 \mu \mathrm{m})$ was used and separation was performed by mobile phase, methanol: water (60:40), with a flow rate of $0.8 \mathrm{~mL} \mathrm{~min}^{-1}$. Capsaicin (Sigma, 98\%) was identified using a standard. Standard curves were prepared using serial dilutions of 50,100, 200, and 400. Capsaicin content of two pepper types was presented in Table 1.

\section{Carotenoid analysis}

The carotenoid content of fish muscles was extracted according to the method of Torrissen and Naevdal (1984). Four fish were randomly sampled from each diet treatment per sampling period and used for carotenoid analyses, which were carried out in triplicate. Samples of 1-2 g muscles without bone and adipose tissue, were 
collected by vertical cut in the abdominal cavity between the pelvis and anus and homogenized by a homogenizer before transferring to $10 \mathrm{ml}$ preweighed glass tubes. After the samples were ground in acetone containing anhydrous sodium sulphate with a homogenizer (Ultra-Turrax Roche T 25 Basic), the extractions were made up to $10 \mathrm{~mL}$ with acetone. The samples were stored for 3 days at $4{ }^{\circ} \mathrm{C}$ in a refrigerator, and then extracted three or four times until no more colour could be obtained. The solutions were centrifuged at $5000 \mathrm{rpm}$ for $5 \mathrm{~min}$, and then their absorptions were measured in a spectrophotometer (Shimadzu, UV mini 1240). A similar method was used for the total carotenoid analysis of dried red peppers, but anhydrous sodium sulphate was not needed. Total carotenoid concentration in the fish fillet was determined spectrophotometrically in acetone using extinction coefficients $\left(\mathrm{E}_{1 \%, 1 \mathrm{~cm}}\right)$ of 1900 for astaxanthin (Foss et al., 1984) at $475 \mathrm{~nm}$, and 2500 for carotenoids from both red peppers at $450 \mathrm{~nm}$ (Schiedt and Liaaen-Jensen, 1995). Total carotenoid content of dried red peppers is given in Table 1.

\section{Sensory analysis}

Sensory evaluation was performed only for fish fed diets containing $4.4 \%$ hot or sweet red pepper and control group. Five expert panellists evaluated the differences in the taste, flavour and appearance using a 5-point hedonic scale (1=like a lot, $3=$ neither like nor dislike, $5=$ dislike a lot) (Meilgaard et al., 1991). Before presenting to the panellists, whole and filleted fish were placed in a dish for evaluating appearances. For taste and flavour analyses the samples (skinless fillet) were cooked individually in a microwave oven at full power (1200 watt) for 5 min and immediately presented to the panellists. The colour assessment was performed in the muscle using the Roche colour card for salmonids. Panel tests were repeated three times. Average scores for each parameter were calculated. Samples were served the tasters in isolated booths illuminated with white light. The taste analyses were conducted in a dark room to prevent any colour differences from influencing panellists' perceptions of taste. Distilled water was freely available for palate to clean their mouth prior to and during tasting.

\section{Statistical analysis}

Data on weight gain of the fish and total carotenoid content of fish fillet are expressed as means \pm s.e. Data from each treatment diet for each sampling period were analysed by one-way ANOVA, and significant differences (if present) were ranked with Duncan's multiple comparison test at the 5\% level of significance by using SPSS 11 for Windows. Sensory data were analysed by non-parametric Kruskal-Wallis test.

\section{Results}

\section{Growth}

All fish grew normally, and no specific signs of disease were observed. All diets were accepted equally well by the fish. Fish weight increased 3-fold at the end of the feeding trial of 80 days. While average initial weights of fish were 58.0 to $60.1 \mathrm{~g}$, 
they varied between 178.92 and $194.30 \mathrm{~g}$ at the end of the experiment (Table 3); however, there was no significant difference in the weight gain of the fish $(\mathrm{P}>0.05)$. Similar results were observed on fish length, condition factor, specific growth rate and feed conversion ratio (Table 4).

Table 3. Average weights of the fish fed different diets

\begin{tabular}{l|c|c|c|cc}
\hline \multirow{2}{*}{\multicolumn{1}{c|}{ Diets }} & \multicolumn{5}{c}{ The average weight of the fish $(\mathrm{g})$} \\
\cline { 2 - 6 } & Day 0 & Day 20 & Day 40 & Day 60 & Day 80 \\
\hline 0.5\% Hot red pepper & $60.12 \pm 0.55$ & $82.71 \pm 0.98$ & $108.51 \pm 1.40$ & $140.03 \pm 2.17$ & $184.16 \pm 3.6$ \\
2\% Hot red pepper & $57.97 \pm 0.56$ & $80.62 \pm 0.90$ & $105.29 \pm 1.49$ & $136.83 \pm 2.31$ & $179.53 \pm 2.96$ \\
4.4\% Hot red pepper & $59.74 \pm 0.52$ & $82.21 \pm 0.83$ & $106.96 \pm 1.66$ & $136.78 \pm 2.63$ & $182.04 \pm 3.81$ \\
0.5\% Sweet red pepper & $57.95 \pm 0.55$ & $80.28 \pm 0.84$ & $107.71 \pm 1.50$ & $136.87 \pm 2.23$ & $179.65 \pm 3.17$ \\
2\% Sweet red pepper & $58.33 \pm 0.57$ & $80.96 \pm 0.89$ & $106.11 \pm 1.51$ & $136.86 \pm 2.21$ & $178.92 \pm 3.11$ \\
4.4\% Sweet red pepper & $58.52 \pm 0.52$ & $79.31 \pm 0.86$ & $106.31 \pm 1.51$ & $138.80 \pm 2.55$ & $184.05 \pm 4.19$ \\
Without red pepper & $58.94 \pm 0.58$ & $83.38 \pm 0.91$ & $111.54 \pm 1.47$ & $145.25 \pm 2.19$ & $194.30 \pm 3.14$ \\
\hline
\end{tabular}

Each value is a mean \pm s.e. ( $\mathrm{n}=2$ replicates). Each replicate consists of measurement of $35 \mathrm{fish}(\mathrm{P}>0.5)$.

Table 4. Some final culture parameters of the fish fed different diets $(\mathrm{P}>0.05)$

\begin{tabular}{l|c|c|c|c}
\hline \multirow{2}{*}{\multicolumn{1}{c}{ Diets }} & \multicolumn{4}{|c}{ Final culture parameters of the fish } \\
\cline { 2 - 5 } & $\begin{array}{c}\text { Length } \\
(\mathrm{cm})\end{array}$ & $\begin{array}{c}\text { Condition } \\
\text { factor }\end{array}$ & $\begin{array}{c}\text { Specific growth } \\
\text { rate }\end{array}$ & $\begin{array}{c}\text { Feed conversion } \\
\text { ratio }\end{array}$ \\
\hline $0.5 \%$ Hot red pepper & $24.16 \pm 0.13$ & $1.25 \pm 0.009$ & $1.36 \pm 0.09$ & $1.30 \pm 0.09$ \\
2\% Hot red pepper & $23.79 \pm 0.13$ & $1.25 \pm 0.010$ & $1.38 \pm 0.12$ & $1.31 \pm 0.08$ \\
$4.4 \%$ Hot red pepper & $23.97 \pm 0.14$ & $1.24 \pm 0.010$ & $1.39 \pm 0.10$ & $1.32 \pm 0.08$ \\
$0.5 \%$ Sweet red pepper & $23.87 \pm 0.14$ & $1.24 \pm 0.010$ & $1.39 \pm 0.11$ & $1.31 \pm 0.07$ \\
$2 \%$ Sweet red pepper & $23.75 \pm 0.12$ & $1.24 \pm 0.010$ & $1.37 \pm 0.11$ & $1.31 \pm 0.09$ \\
$4.4 \%$ Sweet red pepper & $24.09 \pm 0.15$ & $1.24 \pm 0.010$ & $1.40 \pm 0.08$ & $1.29 \pm 0.09$ \\
Without red pepper & $24.20 \pm 0.12$ & $1.26 \pm 0.006$ & $1.43 \pm 0.12$ & $1.22 \pm 0.11$ \\
\hline
\end{tabular}

Each value is a mean \pm s.e. $(n=8)(P>0.5)$.

\section{Pigmentation and sensory properties}

As shown in Table 5, after 20 days of feeding, the total carotenoid content in fillet of the fish fed diets supplemented with increasing amount of red peppers in diet started to differ from that of the fish fed control diet. At the beginning of the experiment, while carotenoid level in the fish fillet was $0.57 \mathrm{mg} \mathrm{kg}^{-1}$, this value rose significantly at the end of the experiment to $1.63-4.36 \mathrm{mg} \mathrm{kg}^{-1}$ in that of fish fed diets containing red peppers. On the other hand, the carotenoid content of the control group increased to only $1.44 \mathrm{mg} \mathrm{kg}^{-1}$ in same period. Hot or sweet red peppers addition of 2 and $4.4 \%$ in diet led to more total carotenoid accumulation in the fish fillet compared to the red peppers addition of $0.5 \%$ and control diet at the end of the experiment $(\mathrm{P}<0.05)$. On the other hand, the total carotenoid depositions between the fillet of fish fed diets containing the same percentage of sweet and hot red pepper were not significantly different $(\mathrm{P}>0.05)$. 
As can be seen in Table 6, the effects of hot or sweet red pepper on all the sensorial properties of fish fillet were found similar $(\mathrm{P}>0.05)$. On the other hand, fish fed both types of red pepper exhibited higher appearance and colour scores compared to the control group $(\mathrm{P}<0.05)$.

Table 5. Total carotenoid contents in the fillet of fish fed different diets

\begin{tabular}{l|c|c|c|cc}
\hline \multirow{2}{*}{ Diets } & \multicolumn{5}{c}{ Total carotenoid contents $(\mathrm{mg} / \mathrm{kg})$ on sampling days } \\
\cline { 2 - 6 } & Day 0 & Day 20 & Day 40 & Day 60 & Day 80 \\
\hline 0.5\% Hot red pepper & $0.57 \pm 0.01 \mathrm{a}$ & $1.01 \pm 0.09 \mathrm{dcb}$ & $1.07 \pm 0.12 \mathrm{c}$ & $1.30 \pm 0.19 \mathrm{c}$ & $1.73 \pm 0.14 \mathrm{c}$ \\
2\% Hot red pepper & $0.57 \pm 0.01 \mathrm{a}$ & $1.16 \pm 0.08 \mathrm{cb}$ & $1.85 \pm 0.17 \mathrm{~b}$ & $2.27 \pm 0.21 \mathrm{~b}$ & $2.79 \pm 0.24 \mathrm{~b}$ \\
4.4\% Hot red pepper & $0.57 \pm 0.01 \mathrm{a}$ & $1.76 \pm 0.21 \mathrm{a}$ & $2.87 \pm 0.22 \mathrm{a}$ & $3.63 \pm 0.16 \mathrm{a}$ & $4.36 \pm 0.29 \mathrm{a}$ \\
0.5\% Sweet red pepper & $0.57 \pm 0.01 \mathrm{a}$ & $0.95 \pm 0.11 \mathrm{dc}$ & $1.08 \pm 0.26 \mathrm{c}$ & $1.29 \pm 0.14 \mathrm{c}$ & $1.63 \pm 0.10 \mathrm{c}$ \\
2\% Sweet red pepper & $0.57 \pm 0.01 \mathrm{a}$ & $1.17 \pm 0.09 \mathrm{~b}$ & $1.84 \pm 0.18 \mathrm{~b}$ & $2.26 \pm 0.14 \mathrm{~b}$ & $2.77 \pm 0.25 \mathrm{~b}$ \\
4.4\% Sweet red pepper & $0.57 \pm 0.01 \mathrm{a}$ & $1.77 \pm 0.13 \mathrm{a}$ & $2.76 \pm 0.23 \mathrm{a}$ & $3.49 \pm 0.26 \mathrm{a}$ & $4.27 \pm 0.21 \mathrm{a}$ \\
Without red pepper & $0.57 \pm 0.01 \mathrm{a}$ & $0.84 \pm 0.16 \mathrm{~d}$ & $0.99 \pm 0.18 \mathrm{c}$ & $1.18 \pm 0.18 \mathrm{c}$ & $1.44 \pm 0.12 \mathrm{c}$ \\
\hline
\end{tabular}

Each value is a mean \pm s.e. Each replicate consists of measurement of four fish. Means within the same column with different letters are significantly different from each other for each sampling day $(\mathrm{P}<0.05)$.

Table 6. Sensory scores in the fillet of the fish fed hot and sweet red pepper diets

\begin{tabular}{l|c|c|c|c}
\hline \multirow{2}{*}{\multicolumn{1}{c}{ Diets }} & \multicolumn{4}{c}{ Sensory scores } \\
\cline { 2 - 5 } & Taste & Flavour & Appearance & Colour \\
\hline $4.4 \%$ Sweet red pepper & $4.85 \pm 0.05 \mathrm{a}$ & $4.18 \pm 0.06 \mathrm{a}$ & $4.04 \pm 0.06 \mathrm{a}$ & $13.18 \pm 0.18 \mathrm{a}$ \\
$4.4 \%$ Hot red pepper & $4.90 \pm 0.07 \mathrm{a}$ & $4.25 \pm 0.03 \mathrm{a}$ & $4.09 \pm 0.04 \mathrm{a}$ & $13.23 \pm 0.20 \mathrm{a}$ \\
Without red pepper & $4.79 \pm 0.06 \mathrm{a}$ & $4.12 \pm 0.05 \mathrm{a}$ & $2.13 \pm 0.06 \mathrm{~b}$ & $11.66 \pm 0.22 \mathrm{~b}$ \\
\hline
\end{tabular}

Each value is a mean \pm s.e. $(n=5)$. Means within the same column with different letters are significantly different from each other for each sampling day $(\mathrm{P}<0.05)$.

\section{Discussion}

The present results indicate that capsaicin, responsible for the hot taste in red pepper, did not affect growth parameters, total carotenoid accumulation and sensory properties in the rainbow trout. In a different animal group, it has been claimed that capsaicin from red pepper leads to more weight gain in broilers (Galib et al., 2011) and increases carotenoid deposition of yolk in laying hens (Gurocak, 1983; Gonzalez et al., 1999; Vicente et al., 2007). However, a study on this topic in fish has not yet been encountered. Furthermore, although it has been claimed that carotenoid from red pepper increased growth in rainbow trout (Talebi et al., 2013) and improved reproductive performance in yellow tail (Agius et al., 2001; Agius et al., 2002), in our study, we have not found any significant effects of carotenoids on growth parameters of rainbow trout.

Total carotenoid accumulation in the fish muscle increased significantly with increasing inclusion of sweet or hot red pepper in the current study. However, only the 
diet consisting of $4.4 \%$ red peppers provided adequate carotenoid accumulation in fillet of the fish, that is, the desired colouration with $4.27-4.36 \mathrm{mg} \mathrm{kg}^{-1}$ carotenoid deposition in the tissue, since the level of $4 \mathrm{mg} / \mathrm{kg}$ in the fish fillet is regarded as a minimum acceptable carotenoid concentration in marketable farmed salmonids (Torrisen et al., 1989). In other studies on red pepper, carotenoid contents found in rainbow trout fillet varied from $1.5 \mathrm{mg} \mathrm{kg}^{-1}$ to $5.6 \mathrm{mg} \mathrm{kg}^{-1}$ depending on feeding period and red pepper level in diet (Vernon-Carter et al., 1994; Yanar et al., 1997; Akhtar et al., 1999; Ergun and Erdem, 2000; Diler and Gökoğlu, 2004).

Although hot and sweet red pepper had similar effects on sensorial properties of the fish, a significant difference was observed between the fish fed diets supplemented with or without carotenoids in terms of colour and appearance. Diler and Gökoğlu (2004) stated that, besides colour scores and appearance, taste scores of fillets from fish fed with red pepper were also found to be higher than those of control group. The authors pointed that the taste perception of the panellists might have been affected by the fish colour. In fact, it is known that fish colour and appearance have influences on several quality parameters of fish, such as freshness, taste and flavour of fish (Anderson, 2000). In our study, because of this risk, we performed the tasting procedure in complete darkness.

As a colour score of 13 or greater obtained using the Roche Colour Card was considered to be an intensity of colour suitable for marketed fish (Smith et al., 1992), the levels of 13.18-13.23 colour score obtained with $4.4 \%$ hot or sweet red pepper was thought to be adequate for desired colouration in the fish in the current study.

Price of $1 \mathrm{~kg}$ of red pepper is 2.5 dollars in Turkey. Therefore, the calculated cost of $4.4 \%$ red pepper containing $66 \mathrm{mg}$ total carotenoid in $1 \mathrm{~kg}$ feed is $\$ 0.11$. This value is similar to the cost of the same amount of synthetic astaxanthine (\$0.10). Even though it is claimed that synthetic astaxanthin provides more carotenoid accumulation compared to red pepper (Vernon-Carter et al., 1994; Yanar et al., 1997), because of public concerns about the use of synthetic additives, red pepper may be an alternative natural carotenoid source for pigmentation of salmonids, particularly in countries where this carotenoid source is cheap, the use of synthetic pigments in fish diets is restricted or organic fish culture is performed. Based on our results, it should also be noted that the type of red pepper to be used in pigmentation of salmonids is not important.

\section{Conclusions}

Since both hot and sweet red pepper had the same effect on the growth, pigmentation and sensory properties of the fish, both types can be considered as appropriate to be utilized as alternative natural carotenoid sources in rainbow trout diets. In order to obtain the desired colouration, a level of at least $4.4 \%$ dried red pepper inclusions into diets can be recommended.

\section{References}

Agius R.V., Watanabe T., Satoh S., Kiron V., Imaizumi H., Yamazaki T., Kawan o K. (2001). Supplementation of paprika as a carotenoid source in soft-dry pellets for broodstock yellowtail Seriola quinqueradiata (Temminck and Schlegel). Aquault Res., 32: 263-272. 
Agius R.V., Watanabe T., Imaizumi H., Yamazaki T. (2002). Spawning performance of yellowtail Seriola quinqueradiata fed dry pellets containing paprika and squid meal. Fish Sci., 68: 230-232.

A kht a r P., Gra y J.I., C o o p e r T.H., G a r ling D.L., B o o r e n A.M. (1999). Dietary pigmentation and deposition of $\alpha$-tocopherol and carotenoids in rainbow trout muscle and liver tissue. J. Food Sci., 64: 234-239.

Anders on S. (2000). Salmon colour and the consumer. In: Microbehavior and macro results: Proceedings of the 10th Biennial Conference of the International Institute of Fisheries Economics and Trade Presentations. IIFET, http://oregonstate.edu/dept/IIFET/2000/papers/andersons.pdf. Washington, DC.

And o S., O s a d a K., Hat a n o M., S a n e y o sh i M. (1992). Metabolism of astaxanthin in muscle and ovary from brook trout Salvelius fontinalis. Comp. Biochem. Physiol. B, 96: 355-359.

AOAC Official Method (1984). AOAC Official Methods of Analysis. 14th ed. Washington, DC.

AOAC Official Method (1990). AOAC Official Methods of Analysis. 14th ed. Washington, DC.

Arredondo-Figueroa J.L., P edroza-İslas R., P on e-Palafox J.T., Vernon-Carter E.J. (2003). Pigmentation of Pacific white shrimp (Litopenaeus vannamei) with esterified and saponified carotenoids from red chili (Capsicum annuum) in comparison to astaxanthin. Revista Mexicana de Ingenieria Quimica, 2: 101-108.

B 1 i g h E.G., D y e r W.J. (1959). A rapid method of total lipid extraction and purification. Can. J. Biochem. Physiol., 37: 911-917.

D e very J., M i l b orrow B.V. (1994). $\beta$-carotene isolation reaction mechanism and improved assay procedure. Br. J. Nutr., 72: 397-414.

D i l e r I., G ö k o ğ l u N. (2004). Investigation of sensory properties of the flesh of rainbow trout (Oncorhynchus mykiss) fed diets with astaxanthin, shrimp waste meal and red pepper meal. Eur. Food Res. Tech., 219: 217-222.

Ergun S., Erde m M. (2000). Effect of natural and synthetic carotenoid sources on pigmentation of rainbow trout (Oncorhynchus mykiss). Turk. J. Vet. Anim. Sci., 24: 391-402.

Erkek R., Talug A.M. (1990). Yumurta tavuğu ve kasaplık piliç karmalarında renk maddeleri kullanımı. Yem Sanayii Dergisi, 66: 30-37.

F os s P., S tor ebakken T., S c hi ed t K., Li a en J.S., A u streng E. (1984). Carotenoids in diets for salmonids. I. Pigmentation of rainbow trout with the individual optical isomers of astaxanthin in comparison with canthaxanthin. Aquacult., 41: 213-226.

Galib A.M., Mam d o oh A.M., S a b a J.A. (2011). The effects of using hot red pepper as a diet supplement on some performance traits in broiler. Pak. J. Nutr., 10: 842-845.

G a zi a n o J.M., H e n n e k e n s C.H. (1993). The role of $\beta$-carotene in the prevention of cardiovascular disease. Ann. N. Y. Acad. Sci., 691: 148-155.

Gonzalez M., Castan o E., Avila E., Meji a E.G. (1999). Effect of capsaicin from red pepper (Capsicum sp) on the deposition of carotenoids in egg yolk. J. Sci. Food Agric., 79: 1904-1908.

G o o d w in T.W. (1984). Animals. In: The Biochemistry of Carotenoids, Volume II., Chapman and Hall Press., London, pp. 64-96.

G or m ley T.R. (1992). A note on consumer preference of smoked salmon colour. Irish J. Agr. Food Res., 31: 199-202.

G u r o c a k B. (1983). Effect of red pepper (Capsicum annuum) on folk and pigment of integument of hens. Ankara, Turkey, University of Ankara Press, 468 pp.

Hat a no M., Tak ah a shi K., Tak a ma S., N a k a j i m a S. (1987). Sensory evaluation of the flesh quality of fall chum salmon. Bulletin of the Faculty of Fisheries Hokkaido University, 38: 311-321.

K r i n s k y N.I. (1993). Action of carotenoids in biological systems. Annu. Rev. Nutr., 13: 561-587.

Mayne S.T. (1996). $\beta$-carotene, carotenoids, and disease prevention in humans. FASAB J., 10: 690-701.

M e i 1 g a a r d M., C i vill e G.V., C a r r B.T. (1991). Sensory evaluation techniques. Boca Raton, FL., CRC Press, 2nd ed. 387 pp.

M o e N.H. (1990). Key factors in marketing farmed salmon. Proc. Nutr. Soc. New Zeal., 15: 16-22.

N a ga o A., D uring A., H o s hin o C., Ter a o J., O l s o n J.A. (1996). Stoichiometric conversion of all-trans- $\beta$-carotene to retinal by pig intestinal extract. Arch. Biochem. Biophys, 328: 57-63.

Ostrander J., Martinsen C., Liston J., Mccullough J. (1976). Sensory testing of penreared salmon and trout. J. Food Sci., 41: 386-390. 
P a l o z z a P., Krin s k y N.I. (1992). Astaxanthin and canthaxanthin are potent antioxidants in a membrane model. Arch. Biochem. Biophys., 297: 291-295.

R o und s R.C., G l e n n C.L., B u s h A.O. (1992). Consumer acceptance of brown trout (Salmo trutta) as an alternative species to rainbow trout (Salmo gairdneri). J. Food Sci., 57: 572-574.

S c h i e d t K., Li a a e n - Jen s e n S. (1995). Isolation and analysis. In: Carotenoids, Britton G., Liaaen-Jensen S., Pfander H. (eds). Birkhäuser, Basel, Switzerland, pp. 81-108.

S ig urgi s l a d o t t i r S., P a r r is h C.C., L a 11 S.P., A c k m a n R.G. (1994). Effect of feeding natural tocopherols and astaxanthin on Atlantic salmon (Salmo salar) fillet quality. Food Res. Int., 27: 23-32.

Sigurgis ladottir S., Torris sen O., Li e Ø., Tho mas sen M., Ha fst eins son H. (1997). Salmon quality: Methods to determine the quality parameters. Reviews in. Fish. Sci., 5: 233-252.

S k o n b e r g D.I., H a rd y R.W., B a rrow s F.T., D ong F.M. (1998). Colour and flavour analyses of fillets from farm-raised rainbow trout (Oncorhychus mykiss) fed low-phosphorus feeds containing corn or wheat gluten. Aquacult., 166: 269-277.

S mith B.E., Hardy R.W., Torris e n O.J. (1992). Synthetic astaxanthin deposition in pan-size coho salmon (Oncorhynchus kisutch). Aquacult., 104: 105-119.

S t o r e b a k k en T., N o H.K. (1992). Pigmentation of rainbow trout. Aquacult., 100: 209-229.

Talebi M., Khara H., Z oriehzahra J., Ghobadi S., Khodabandel A., Mirras ooli E. (2013). Study on effect of red bell pepper on growth, pigmentation and blood factors of rainbow trout (Oncorhynchus mykiss). World J. Zool., 8: 17-23.

To p u z A., Ö z d e m i r F. (2007). Assessment of carotenoids, capsaicinoids and ascorbic acid composition of some selected pepper cultivars (Capsicum annuum L.) grown in Turkey. J. Food Comp., 20: 596-602.

Tor r is s e n O.J., N a e v d a l G. (1984). Pigmentation of salmonids - genetic variation in carotenoid deposition in rainbow trout. Aquacult., 38: 59-66.

Tor r i s e n O.J., H a r d y R.W., S h e a r e r K.D. (1989). Pigmentation of salmonids carotenoids deposition and metabolism. Aquat. Sci., 1: 209-225.

Vern o n - C a r t e r E.J., P a l a fox J.T.P., I s l a s R.P. (1994). Bioensayo de pigmentacion de trucha arcoiris (Oncorhynchus mykiss) con extractos de chile ancho (Capsicum annuum). Archivos Latinoamericanos de Nutrición, 44: 252-255.

Vicente J.L., L opez C., Avila E., Morales E., Hargis B.M., Tellez G. (2007). Effect of dietary natural capsaicin on experimental Salmonella enteritidis infection and yolk pigmentation in laying hens. Int. J. Poult. Sci., 6: 393-396.

W o o d b u r y J.E. (1980). Determination of capsicum pungency by high pressure liquid chromatography and spectrofluorometric detection. J. Assoc. Offic. Anal. Chem., 63: 556-558.

Yanar M., Kumlu M., Çe lik M., Yan ar Y., Te keli o ğlu N. (1997). Pigmentation of rainbow trout (Oncorhynchus mykiss) with carotenoids from red pepper. Isr. J. Aquacult-Bamid., 49: 193-198.

Z i e g l e r R.G. (1989). A review of epidemiologic evidence that carotenoids reduce the risk of cancer. J. Nut., 119: 116-122.

Received: 27 X 2015

Accepted: 1 III 2016 